\title{
The Usage of the Article with Nouns Defined by a Nominal or Pronominal Genitive in LXX Genesis
}

\section{Sollamo, Raija}

Vandenhoeck \& Ruprecht

2020

Sollamo , R 2020 , The Usage of the Article with Nouns Defined by a Nominal or Pronominal Genitive in LXX Genesis . in T Kauhanen \& H Vanonen (eds), The Legacy of Soisalon-Soininen : Towards a Syntax of Septuagint Greek . , 3 , De Septuaginta Investigationes (DSI) , vol. 13 , Vandenhoeck \& Ruprecht, Göttingen , pp. 43-53 . https://doi.org/10.13109/9783666

http://hdl.handle.net/10138/335857

https://doi.org/10.13109/9783666564871.43

unspecified

acceptedVersion

Downloaded from Helda, University of Helsinki institutional repository.

This is an electronic reprint of the original article.

This reprint may differ from the original in pagination and typographic detail.

Please cite the original version. 


\title{
The Usage of the Article with Nouns Defined by a Nominal or Pronominal Genitive in LXX Genesis
}

\author{
RAIJA SOLLAMO
}

The usage of the article is an example of grammatical differences between Hebrew and Greek. In Greek, the noun is usually understood as defined if it is connected with a genitive, be it a noun or pronoun in the genitive, and this understanding is marked by the use of the definite article. ${ }^{1}$ In Hebrew, the noun is also understood as defined if it is in the status constructus form before another noun in the status absolutus, which is the way the genitive is expressed in Hebrew. But opposite to the Greek practice, the Hebrew locution leaves the article out with the understanding that the definition is self-evident. ${ }^{2}$ One does not need to mark it with an article unless in connection with an adjective attribute. The main focus of my paper is not, however, on the contrastive grammar, even though it might be very interesting. Rather, it is the translation technique of the Genesis translator that comes to the fore. The question is whether the translator followed the Greek grammatical rules in the usage of the definite article or whether he worked more mechanically on the basis of the Hebrew and left the article out whenever there was no article in the Hebrew Vorlage. Because the translation technique is my final focus, I also include those very freely rendered cases that display no genitive in the Greek and accordingly, the renderings do not actually belong under the title "The Usage of the Definite Article with Nouns Defined by the Nominal or Pronominal Genitive in Greek". This concerns my last section "Free Renderings without the Genitive". Altogether, the number of cases to be examined is huge. Therefore, I had to confine this paper to the Greek Genesis. In order to interpret the translator's working habits and thinking correctly, Muraoka's new Syntax of Septuagint Greek is a helpful tool in providing some categories of the usage of the article in the Septuagint on the basis of Greek. ${ }^{3}$

\footnotetext{
${ }^{1}$ Eduard Schwyzer - Albert Debrunner, Syntax und syntaktische Stilistik. Griechische Grammatik II. München: C.H. Beck'sche Verlagsbuchhandlung, 1950, 19-27. Jerker Blomqvist og Paul Ole Jastrup, Grekisk - graesk Grammatik. Odense: Akademisk Forlag, 1990, § 224-225 (pp. 169-171).

${ }^{2}$ E. Kautzsch, Gesenius' Hebrew Grammar, $2^{\text {nd }}$ English ed. revised by A.E. Cowley. Clarendon Press: Oxford, 1910 (20 ${ }^{\text {th }}$ impression, 1990), $\S 127$ a (p. 410). "In a construct chain, the construct can never be prefixed with the article. The definiteness of the genitive specifies the definiteness of the phrase." Bruce K. Waltke -M.O'Connor, An Introduction to Biblical Hebrew Syntax. Winona Lake, Indiana: Eisenbrauns, 1990, § 9.7 (pp.156-157).

${ }^{3}$ T. Muraoka, A Syntax of Septuagint Greek. Leuven - Paris - Bristol, CT: Peeters, 2016.
} 


\section{The Definite Article}

The most common practice the Genesis translator follows is to use the definite article before a noun which is followed by a nominal or pronominal genitive. ${ }^{4}$ This happens in circa 1940 out of 2470 cases $(78.5 \%)$ in the Greek Genesis. The examples are of various kinds and there seems to be no difference for the translator whether the Hebrew noun is determined by another noun in the genitive or by a pronominal suffix.

\section{Examples}

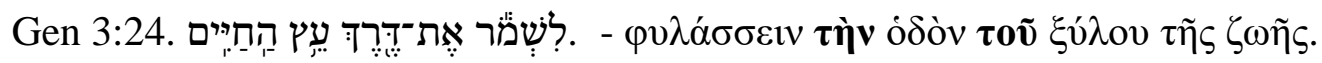

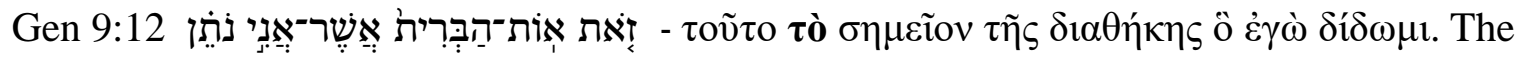
definition of $\tau$ ò $\sigma \eta \mu \varepsilon \tilde{o} v$ is reinforced by both the genitive and the relative clause.

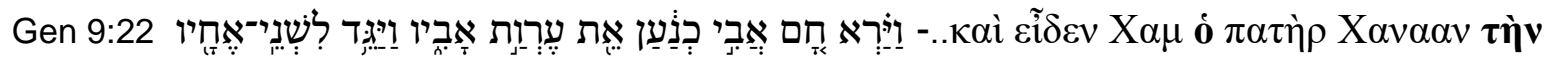

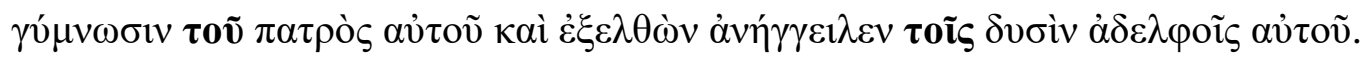

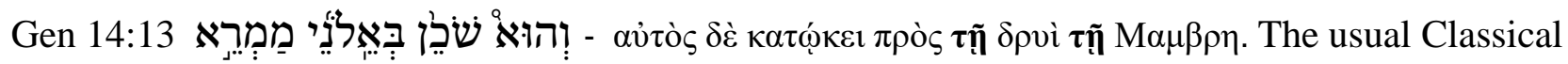
Greek practice of repeating the article of the regens before a genitive attribute ${ }^{5}$ seldom appears in LXX Genesis, mostly in connection with the genitives of Hebrew proper names (see also Gen 14:1).

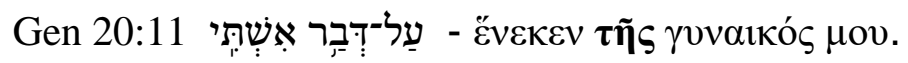

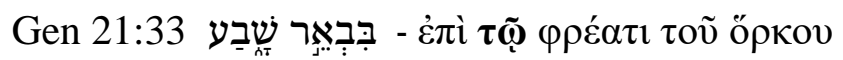

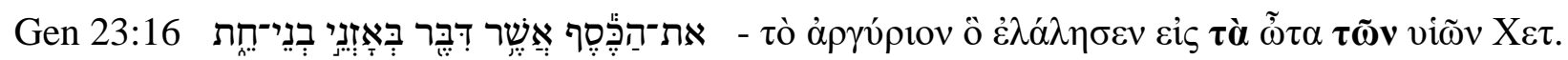

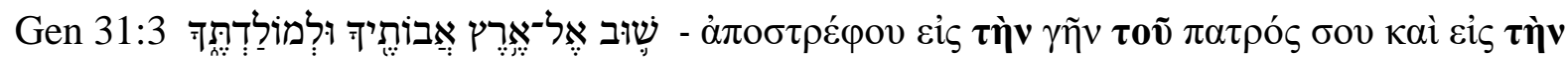
$\gamma \varepsilon v \varepsilon \alpha ́ v ~ \sigma o v$.

\footnotetext{
${ }^{4}$ This is the normal word order. The usual practice of using the definite article does not change in cases where the genitive is placed before the noun. In these few cases the genitive is situated either before the arthrous noun or between the article and the noun. With the genitive of the relative pronoun the article and the noun follow the relative pronoun.

${ }^{5}$ Schwyzer - Debrunner II, B, 1 f $\gamma$ (p. 26).
} 


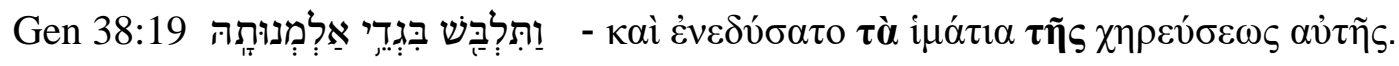

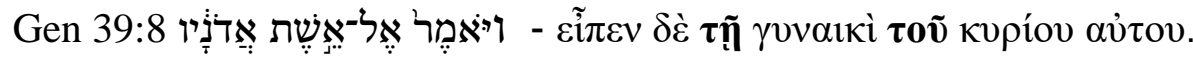

The use of the definite article with a noun determined by another noun in the genitive or by a possessive pronoun (or another pronoun) shows the translator's good competence in Koine Greek. His competence also guides him in instances where the parent text has a shorter or lengthy chain of coordinate expressions with the same suffix. He then understands that he does not have to repeat the possessive pronoun with every item, but the definite article suffices [e.g. Gen 32:23(22)]. ${ }^{6}$

It has also been suggested that the translator adhered to the length of the Hebrew expression in that he easily used the definite article in instances where the Hebrew has the nota accusativi or a preposition, such as ??, before the noun in the status constructus. This practice was characteristic of Aquila. ${ }^{7}$ To form an opinion I have haphazardly checked 700 cases where the definite article appears. In them the nota accusativi is found 102 times and $\zeta 53$ times. Thus, the cases with אֶ form only $14.6 \%$ of all the instances with the definite article in my checked 700 cases. Since the correspondence of the other prepositions with the use of the definite article is minor, we can safely conclude that for the Genesis translator the Hebrew nota accusativi or basic prepositions did not play any significant role for the use of the definite article in his Greek translation. The real reason for the usage of the definite article by the translator seems to be his good command of Greek. He shows no endeavour in the direction of a slavish translation in the style of Aquila.

\section{Special cases}

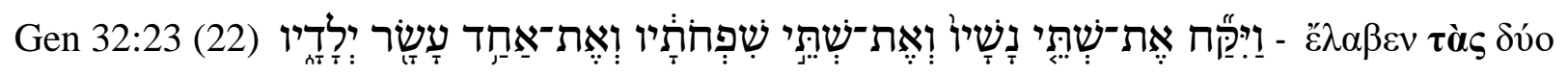

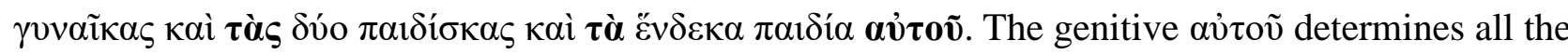
items, even though it is not repeated.

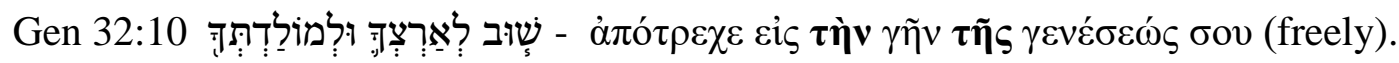

\footnotetext{
${ }^{6}$ Sollamo, Repetition of the Possessive Pronouns in the Septuagint. Septuagint and Cognate Studies 40. Atlanta, Georgia: Scholars Press, 1995, 22-29.

${ }^{7}$ Ilmari Soisalon-Soininen, "Einige Merkmale der Ûbersetzungsweise von Aquila." Ilmari SoisalonSoininen, Studien zur Septuaginta-Syntax. Zu seinem 70. Geburtstag am 4. Juni 1987 herausgegeben von Anneli Aejmelaeus und Raija Sollamo. Annales Academiae Scientiarum Fennicae Ser. B, Tom. 237. Helsinki: Suomalainen Tiedeakatemia, 1987, 19-27. Soisalon-Soininen writes: "Wenn im Hebräischen kein Artikel steht, wird er auch bei Aquila weggelassen, wenn nicht ein anderes hebräisches Wörtchen (nota acc. oder ? ) mit ihm wiedergegeben ist." (p. 21).
} 


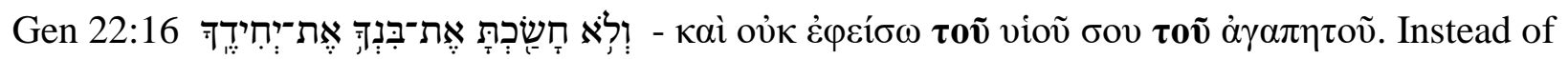

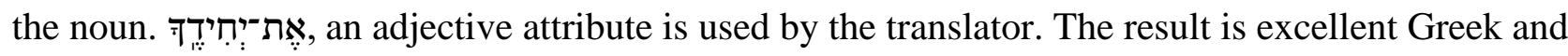
corresponds well to the meaning of the Hebrew clause.

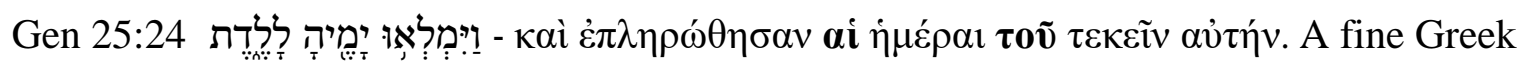
rendering with a genitive of an infinitive. Another example appears in Gen 2:9.

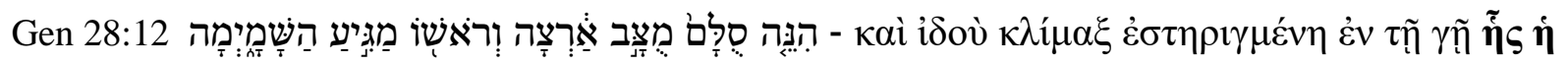

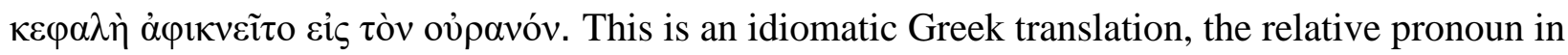
the genitive referring to the ladder. Furthermore, it changes the Hebrew parataxis into a more refined Greek clause structure.

These and the other special cases attest the freedom of the Genesis translator as regards his parent text but they also demonstrate his great competence in producing good Koine Greek. If we evaluate the possible Hebraic flavor or Hebrew interference in his translation, we could direct our attention to the abundant use of the possessive pronouns, i.e. the genitives of the

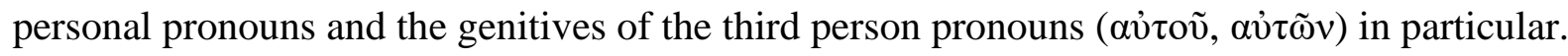

\section{No Article with the Noun Defined by the Genitive}

The second largest group consists of instances where the noun determined by a nominal or pronominal genitive remains without an article in the Greek translation. The structure strictly adheres to the Hebrew expression of the genitive where the noun in status constructus (the regens) does not have an article. These cases appear 530 times (21.5\%) in the Greek Genesis. As the use of the definite article is overwhelming $(78.5 \%)$ with the nouns defined by a nominal or pronominal genitive, the omission of the article is a marked alternative according to modern linguistics. Even though the translator did not master modern linguistics, it is reasonable to suppose that the omission of the article was a choice that had good reasons in his translating. Of course, the absence of an article now and then might be a slip, due to the influence of the Hebrew parent text (interference). Nevertheless, in most cases the translator's thinking and his language ability come clearly to the fore. This can be concluded from the groups of instances following the same anarthrous translational patterns. 
A very marked rule the translator follows is the usual Greek practice of leaving the predicate of a descriptive nominal clause anarthrous if it is contextually indeterminate. ${ }^{8}$ There appear a number of instances of this phenomenon, such as

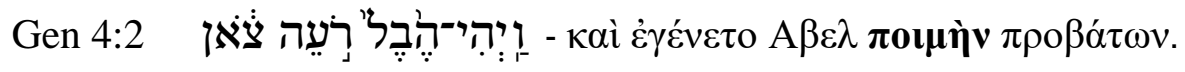

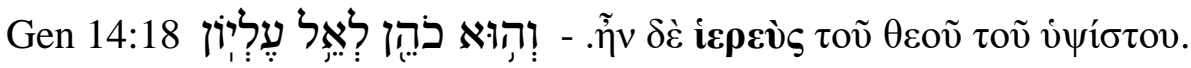

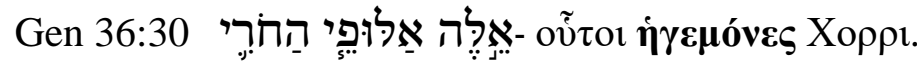

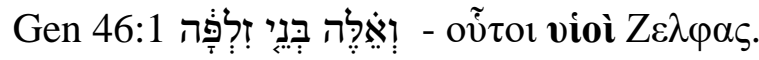

In Genesis 36 the idioms (oṽ proper name in the genitive are frequently repeated. The idiom (oṽ $\tau$ ) $)$ viò + a proper name in the genitive recurs a number of times in the long list of Jacob's sons and grandsons in Genesis 46, too. Some manuscripts add the definite article in these instances.

The names of family members are often used without an article without any strict logic as, for instance, in

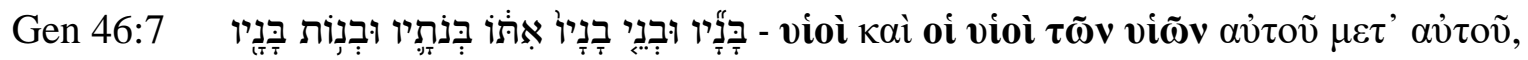

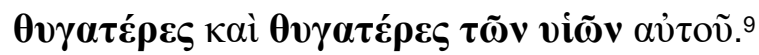

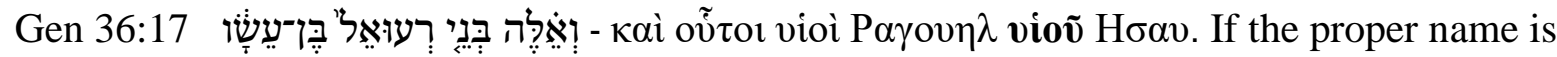
followed by a patronymic, matronymic or an apposition of the similar type, the noun denoting the family connection is mostly without the article. This happens in the genealogical lists in particular: ${ }^{10}$

\footnotetext{
${ }^{8}$ T. Muraoka, A Syntax $\S 3 \mathrm{c}$ (pp. 13-14).

${ }^{9}$ Edwin Mayser, Grammatik der griechischen Papyri aus der Ptolemäerzeit. Band II 2 Satzlehre, Analytischer Teil, zweite Hälfte . Berlin und Leipzig: Walter de Gruyter \& Co, 1933. § 57, 2 b Anmerk. (p.

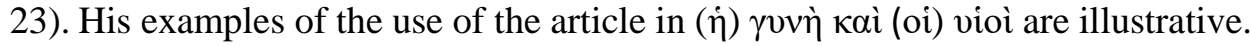

${ }^{10}$ Muraoka, A Syntax, does not consider the patronymics or matronymics $\S 3 \mathrm{~b}$ (pp.12-13). In expressions of origin by birth the nouns for patronymics and matronymics often appear without the article as the examples of Schwyzer - Debrunner show. Eduard Schwyzer - Albert Debrunner, Syntax und syntaktische Stilistik. Griechische Grammatik II. München: C.H. Beck'sche Verlagsbuchhandlung, 1950, e III $2 \gamma$ (p. 124). See also Mayser, Grammatik II 2, § 57, 2a (p. 22).
} 


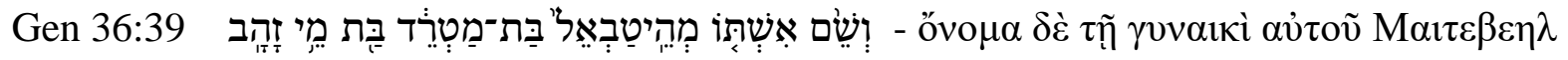

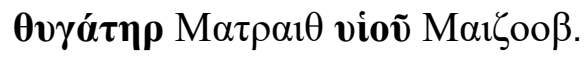

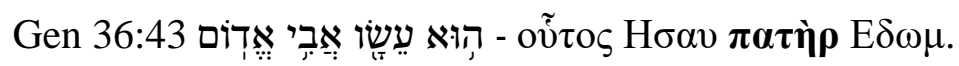

In the long list of the sons and grandsons of Jacob in Genesis 46, the nouns are usually anarthrous:

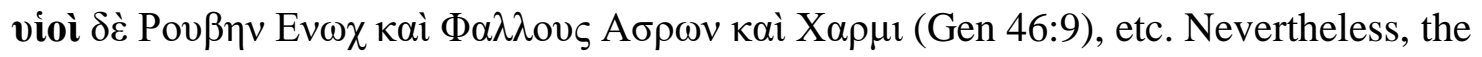

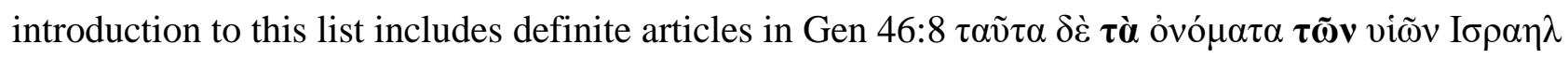

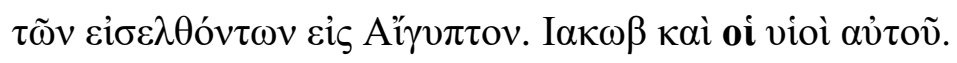

One category of anarthrous nouns consists of such titles as $\beta \alpha \sigma i \lambda \varepsilon v ́ \varsigma$ and $\dot{\eta} \gamma \varepsilon \mu \omega ́ v$. They are used without an article before a personal or geographical proper name in LXX Genesis. The anarthrous use of $\beta \alpha \sigma i \lambda \varepsilon v$ $\varsigma$ as a title is also attested in contemporary Koine sources. ${ }^{11}$ Examples:

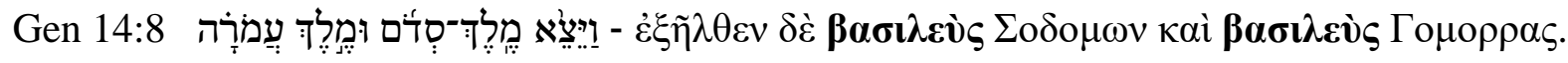

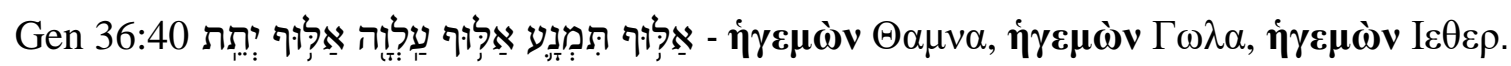

One fascinating group of instances consists of geographical proper names in Hebrew and their Greek renderings, and in particular those that are formed with the noun $\gamma \tilde{\eta}$ “country" (regens) and an anarthrous proper name (rectum). There appear 60 cases altogether in

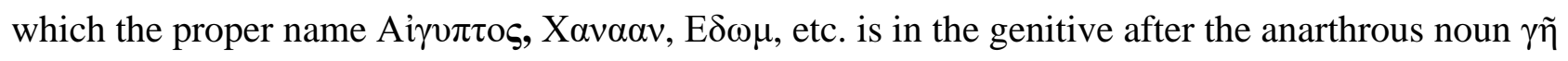
in the genitive, dative or accusative ${ }^{12}$ and 11 cases where the "country" is in the dative and the

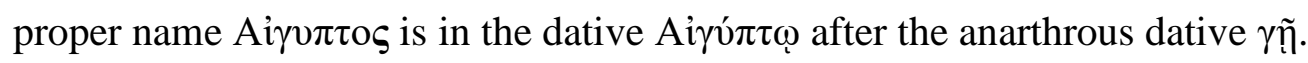

Examples:

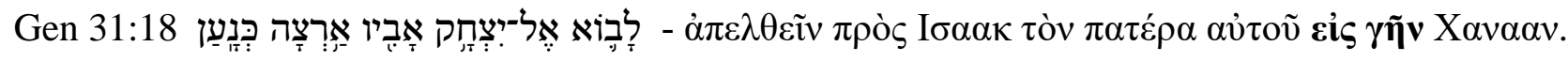

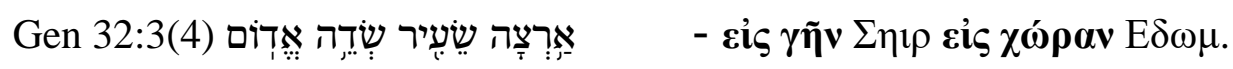

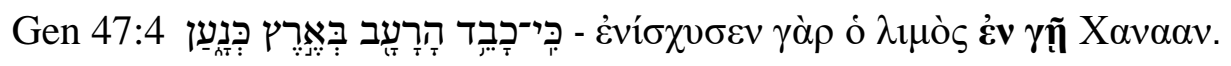

\footnotetext{
${ }^{11}$ Mayser, Grammatik II 2, § 582 b (p. 27).

${ }^{12}$ The translator is not fully consistent in the use of the article. Two examples of $\gamma \tilde{\eta}$ with the article: Gen

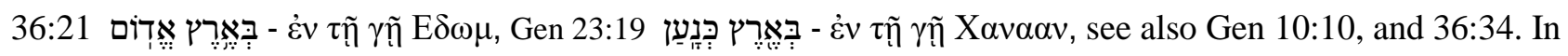
the nominative the article usually appears (Gen 13:10, 41:55, 47:6, 47:13 bis, e.g. Gen 13:10 $\dot{\omega} \varsigma \dot{\eta} \gamma \tilde{\eta}$ Airvi $\pi \tau$ ov), occasionally also in the genitive and accusative if they are not connected with a preposition (Gen 2:11, 2:13, 17:8, 41:34, and 50:11).
} 


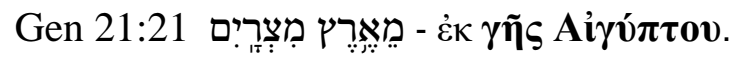

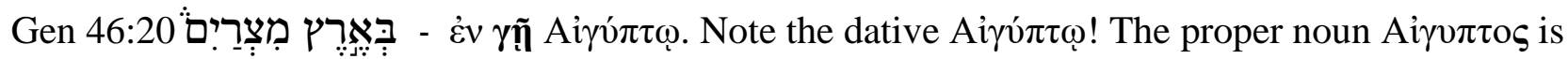
found both in the dative and in the genitive after the anarthrous dative $\gamma \tilde{\mathbf{n}}$ (dative in $41: 19 ; 41: 29$; $41: 30 ; 41: 36 ; 41: 53 ; 46: 20 ; 46: 27 ; 47: 11 ; 47: 14 ; 47: 27 ; 47: 28$; genitive in $41: 44 ; 41: 48 ; 41: 54)$, while after the anarthrous genitive and accusative it appears in the genitive (after a genitive 21:21; $41: 33 ; 41: 43 ; 45: 8 ; 45: 9 ; 45: 26 ; 47: 15$; after an accusative $41: 46)$. Which is the older or more original reading the dative or the genitive after the dative $\boldsymbol{\gamma} \tilde{\mathbf{n}}$, is a challenging text-critical problem. Soisalon-Soininen, when studying the status constructus cases, presented statistics for the relation of the occurrences of the dative and genitive after the dative $\gamma \tilde{n}$ and clearly demonstrated that the dative is more common than the genitive in all books of the Pentateuch, the relations are 10:3 in Genesis, 16:10 in Exodus, 1:0 in Leviticus, 3:1 in Numeri and 9:0 in Deuteronomy. ${ }^{13}$ The witnesses are strongly divided and accordingly, it is impossible to reach one and the same solution in every occurrence, but the variation between the dative and the genitive remains. ${ }^{14}$ I give here an example of the unanimity of the mss.

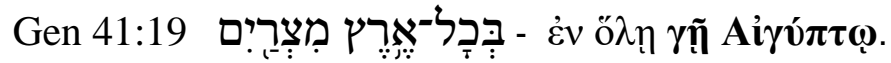

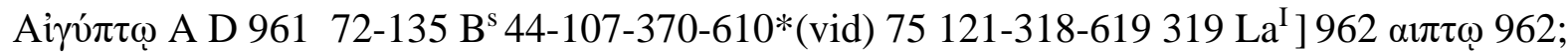
$>408^{*} ;-\pi \tau$ ov $\mathrm{La}^{\mathrm{S}}$ rell.

Fixed idioms and grammaticalized expressions consisting of a preposition and a noun usually appear without an article in LXX Genesis and in Koine sources. The renderings of Hebrew semiprepositions that consist of a preposition and a noun belong to this group of instances (19 cases). ${ }^{15}$

Examples:

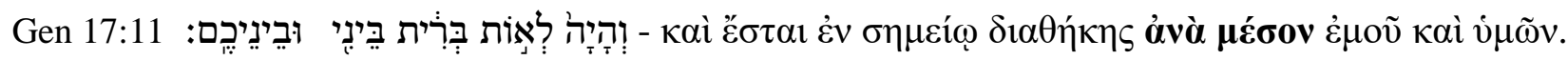

\footnotetext{
${ }^{13}$ Soisalon-Soininen, "Verschiedene Wiedergaben der hebräischen status constructus-Verbindung im griechischen Pentateuch" in his Studien zur Septuaginta-Syntax. Helsinki: Suomalainen Tiedeakatemia, 1987, 62-70. For Genesis the figures should be 11:3, as the text above demonstrates.

${ }^{14}$ I have followed Wevers' decisions in his critical text of the Göttingen Septuaginta. Septuaginta Vetus Testamentum Graecum Auctoritate Academiae Scientiarum Gottingensis editum vol. I Genesis, edidit John William Wevers. Göttingen: Vandenhoeck \& Ruprecht, 1974.

${ }^{15}$ See more in Sollamo, Renderings of Hebrew Semiprepositions in the Septuagint. AASF Diss. hum.litt. 19. Helsinki: Suomalainen Tiedeakatemia, 1979.
} 


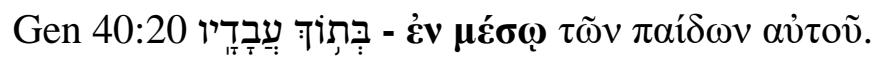

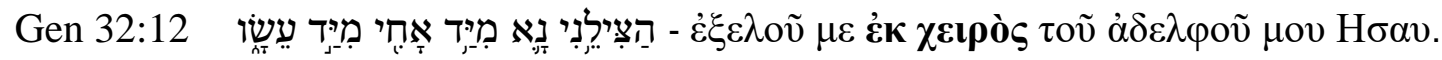

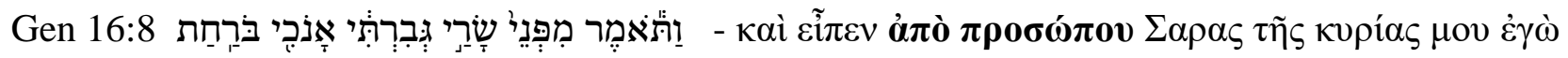
$\grave{\alpha} \pi \circ \delta 1 \delta \rho \alpha ́ \sigma \kappa \omega$.

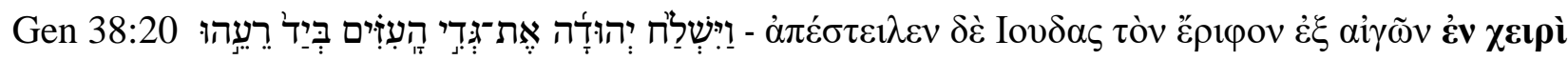

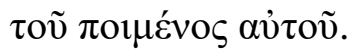

Other examples of fixed expressions used without an article also appear. The absence of the article could be considered due to Hebrew interference or "reinforced by the underlying Semitic syntagm with the necessarily anarthrous NP (Noun Phrase) in the st.c..." ${ }^{16}$ Nevertheless, this is not very likely, since the principal method of the Genesis translator was to use the definite article in rendering nouns in the status constructus defined by another noun in the status absolutus or defined by a pronominal suffix. Thus, the omission of the article was - at least mostly - a marked alternative based on the translator's command of Greek. ${ }^{17}$

Examples:

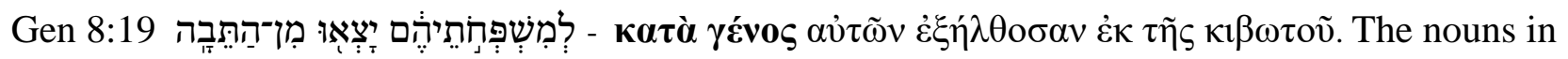
distributive expressions after the preposition $\kappa \alpha \tau \alpha$ are usually anarthrous in Greek sources. ${ }^{18}$ Gen 10:3.

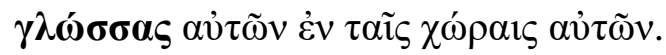

Gen 17:11

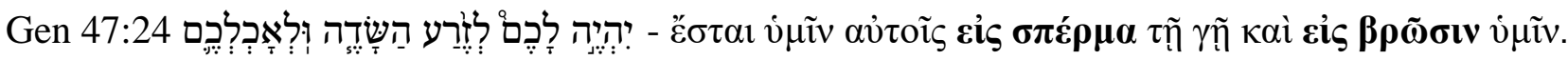
The last example shows how close the genitive and dative are to one another. Cases of this kind belong to free renderings in my classification because there is no genitive in the Greek. Here the use of the datives is a fine insight by the translator.

\footnotetext{
${ }^{16}$ Cf. Muraoka, A Syntax $\S 3$ a. See also, however, note 2 (p. 12).

${ }^{17}$ Raphael Kühner - Bernhard Gerth, Ausführliche Grammatik der griechischen Sprache II:1 Satzlehre, 3. Aufl. $\$ 462$ (pp. 598-610). After a preposition the article is often omitted $\S 462$, f (p. 605).

${ }^{18}$ See the examples in Schwyzer - Debrunner, Syntax 2b a 10 (pp. 473-481). Cf. Mayser, Grammatik II 2, § 57,3 b (p. 24).
} 
To sum up, the great number of the arthrous examples in relation to the anarthrous examples was a surprise, at least for me. These examples suffice to lead us to the understanding that the instances with no definite article are not at all indifferent or Hebraistic Greek even if they are slavish renderings from the point of view of grammatical structure. The absence of the article is not due to a slavish adherence to the Hebrew syntactic structure, but due to paying attention to the qualities of the target language. Even the anarthrous examples follow good Koine practice and idiom in not using the article. The translator was capable of seeing in which instances an anarthrous noun is idiomatic in Greek. Finally, both the use and non-use of the definite article attest the Genesis translator's considerable competence in Greek. This situation is rare because usually when one studies translation technique he/she is able to find both genuine Koine Greek and Hebraistic translation Greek side by side by the same translator. If and when a Hebraistic instance or an instance of Hebrew interference occurs in this material, it really comprises an individual case and is an exception or a slip in the midst of otherwise correct Koine Greek.

\section{Free Renderings without the Genitive in Greek}

My title was "The Usage of the Article with Nouns Defined by a Nominal or Pronominal Genitive in the LXX Genesis". The task is now fulfilled, but only if we consider the Greek translation. If we should like to conduct a more thorough investigation of translation technique, we should take into the loop all the 2844 Hebrew instances where there appears a status constructus - status absolutus structure or a pronominal suffix attached to a noun in the parent text and find out what has happened to those cases in the Greek translation even when it displays a different structure and freer rendering without the genitive. In other words, these instances are translated so freely that one cannot apply the definitions of my title to them. This is my problem, but it has wider relevance for the study of Septuagint syntax. In my opinion, we should not study the Septuagint syntax paying attention primarily to the Greek target language as Muraoka does in his new syntax and as my title now does. Rather, we should prefer starting from the Hebrew parent text and its structures and features in order to learn to understand the subtle differences between the two languages and in order to give an adequate description of what the translator has achieved. Therefore, I now refer in brief at the end to those cases where the translator has not used a genitive at all. This kind of free renderings comprises 374 instances (circa 13\%).

The most common model for a free rendering is to leave the genitive out and use only the definite article (93 instances). This practice is in accord with Greek idiom in cases where the 
referent is clear from the context. In the Septuagint the genitives of the third persons of the possessive pronoun are anyway found with unidiomatic frequency. Leaving a number of such genitives out shows the great competence of the Genesis translator in Greek. ${ }^{19}$

Examples:

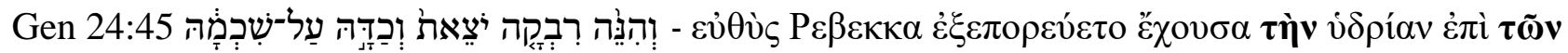
$\dddot{\omega} \mu \omega v$.

Gen 27:31

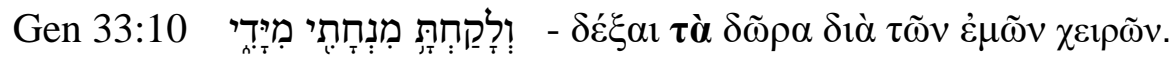

One way of deleting genitives that the translator resorts to is to replace them with datives in Greek. It happens sporadically here and there (as in Gen 47:24 cited above), but most consequently in the cases of the onoma rule (25 instances in LXX Genesis). The onoma rule is valid in Greek idiomatic expressions where the name of a person is introduced: onoma (without the article) + the person whose name is in question in the dative and then the name. ${ }^{20}$ Examples:

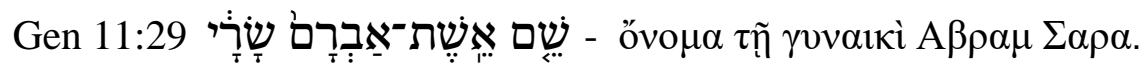

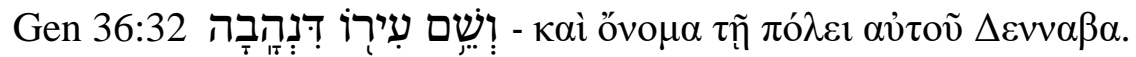

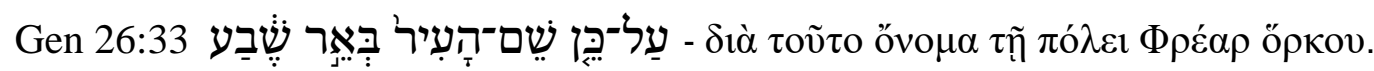

With the aid of the status constructus Hebrew also expresses material and quality (in at least 43 cases), not only possession and belonging. Often this implies that a genitive of quality is translated with an adjective.

Examples:

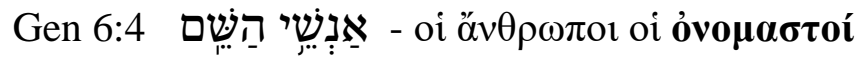

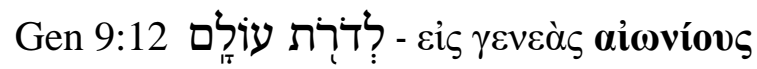

One way to avoid using a genitive is to form the words in the

\footnotetext{
${ }^{19}$ Soisalon-Soininen, "Die Auslassung des Possessivpronomens im griehischen Pentateuch" in his Studien zur Septuaginta-Syntax. Helsinki: Suomalainen Tiedeakatemia 1987, 86-92.

${ }^{20}$ I have given a fuller analysis of these cases in my article under the working title "The Onoma Rule and the Vocative in LXX Genesis" to appear in 2019. See also John A. L. Lee, "The Onoma Rule" Novum

Testamentum 56 (2014), 411-421.
} 
status constructus and status absolutus into a compound word and use it with or without the article (at least 44 instances).

Examples:

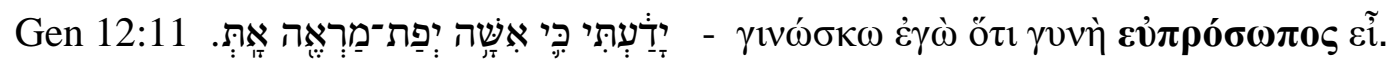

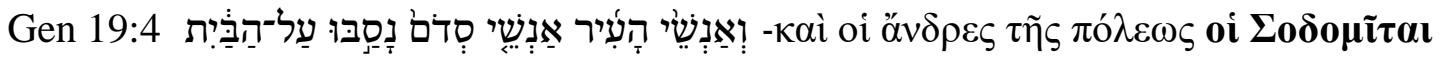

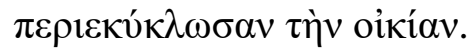

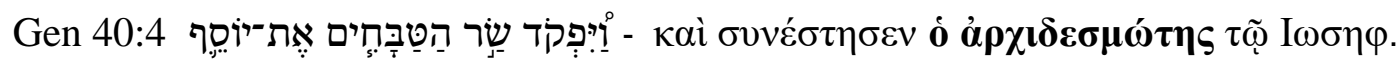

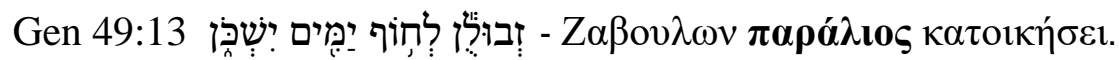

Furthermore, the pronominal suffix of the first person singular often indicates an address corresponding to the Greek vocative case (36 cases in LXX Genesis). ${ }^{21}$

Examples:

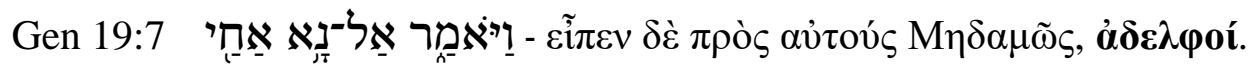

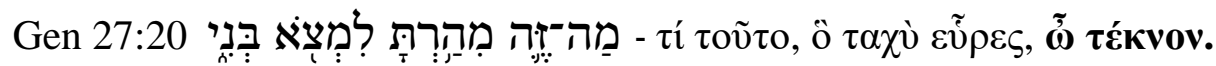

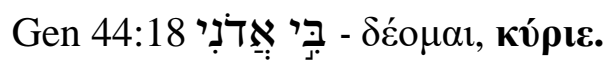

In addition to these instances there appear 53 miscellaneous free renderings which occur sporadically, such as Gen 7:2 and 39:19.

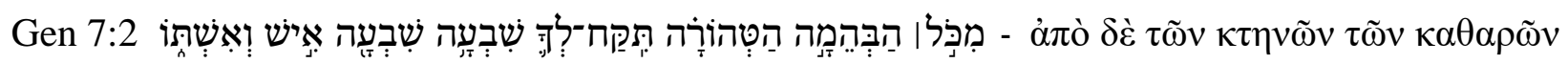

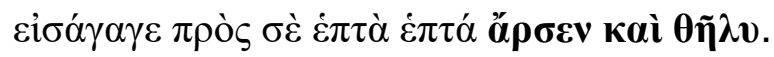

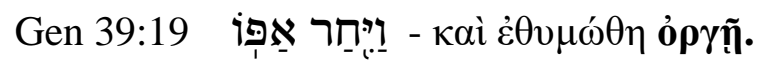

These free renderings demonstrate that the translator felt, at least to a certain extent that his Hebrew parent text had more genitives and possessive suffixes in different uses than what he could afford in his translation in idiomatic Greek. Thus, he changed the structure and rendered freely. The main thing is to be aware of these two different approaches: one keeping within the boundaries of Greek grammar, and another one following the Hebrew grammatical patterns and their Greek renderings even if these are scattered in different grammatical categories. The problem is similar to what Ilmari Soisalon-Soininen met when investigating the Hebrew infinitives and their

\footnotetext{
${ }^{21}$ Here again I refer to my article under the working title "The Onoma Rule and the Vocative in LXX Genesis" to be published in 2019.
} 
renderings in the Septuagint. ${ }^{22}$ He had to leave the infinitivus absolutus cases out of his research because the Hebrew infinitivus absolutus was never translated by an infinitive in Greek. My solution here differs from his in that I refer to the free translations not following the grammatical structure of Hebrew as well. This is done in order to illuminate the vast selection of choices the translator had and mastered. The free renderings are very typical of his way of translating.

\section{Conclusions}

To sum up in brief, the use of the definite article dominates the field before nouns defined by a nominal or pronominal genitive in Greek appearing in 1940 out of 2470 cases (78.5\%). This is a result I did not expect. I anticipated in my mind that the translator followed more strictly the Hebrew usage of the article. This can only be explained by the Genesis translator's proficiency in Greek. In this respect his translation is free from Hebrew interference.

Certainly, there are also found cases without the article before nouns defined by a nominal or pronominal genitive in Greek, 530 out of 2470 cases $(21.5 \%)$. Evaluated from a purely formal viewpoint these instances strictly follow the Hebrew expression in not using the article. It is, however, too hasty to regard all of these cases as witnesses of Hebrew interference. Some of them might show Hebrew interference, but most of them follow Greek practice and idiom as marked renderings chosen by the translator. At any rate, in this group there also exist some inconsistent uses of the anarthrous and arthrous alternatives which might reflect an uncertainty felt by the translator about whether to use or not to use the article or the possibility he regarded both alternatives as equally suitable because the vacillation between the use and non-use of the article in a number of phrases was typical of the contemporary Koine. In these anarthrous cases the influence of Hebrew interference is difficult either to prove or to totally exclude.

The third group of instances consists of the very free renderings which break the Hebrew structure in 374 cases out of 2844 (13.1\%). They are absolutely good Greek and show beyond doubt the translator's superb command of Greek and good command of Hebrew too. He recognizes Hebrew addressing forms and renders them with Greek vocatives, he knows the onoma rule, he diminishes the number of genitives and of genitives of the third person possessive pronouns and is familiar with Greek idioms. He simply writes good idiomatic Greek. Even in his free

\footnotetext{
${ }^{22}$ Ilmari Soisalon-Soininen, Die Infinitive in der Septuaginta. Annales Academiae Scientiarum Fennicae, Ser. B 132,1. Helsinki: Suomalainen Tiedeakatemia, 1965.
} 
renderings he adheres to the meaning of the Hebrew clauses and expressions but renders them by utilizing genuine Greek means. His linguistic competence is so extensive and rich in idiomatic variation that he must have been a native Greek speaker. 